\title{
Erratum to: The beneficial role of proteolysis in skeletal muscle growth and stress adaptation
}

\author{
Ryan A. V. Bell ${ }^{1,2}$, Mohammad Al-Khalaf ${ }^{1,2}$ and Lynn A. Megeney ${ }^{1,2,3^{*}}$
}

Following the publication of the original article [1] the author notified us of an error in the manuscript, which needed to be corrected. The error appears in the following sentence, which can be found under the sub-heading "Caspases and skeletal myoblast differentiation":

"Here, Fernando et al. [29] demonstrated that transient caspase- 3 activity is required for myoblast differentiation and that this non-death activity is mediated in part through the cleavage activation of the Ste-20 like kinase, macrophage stimulating 1 (MST1)"

However, this sentence has now been corrected on the BioMed Central website, and now reads as follows:

"Here, Fernando et al. [29] demonstrated that transient caspase-3 activity is required for myoblast differentiation and that this non-death activity is mediated in part through the cleavage activation of the mammalian sterile 20-like kinase-1, MST1"

\footnotetext{
Author details

${ }^{1}$ Regenerative Medicine Program, Sprott Center for Stem Cell Research, Ottawa Hospital Research Institute, The Ottawa Hospital, Ottawa, ON K1H 8L6, Canada. ${ }^{2}$ Department of Cellular and Molecular Medicine, University of Ottawa, Ottawa, ON, Canada. ${ }^{3}$ Department of Medicine, Division of Cardiology, University of Ottawa, Ottawa, ON, Canada.
}

Received: 26 April 2016 Accepted: 26 April 2016

Published online: 04 May 2016

\section{References}

1. Bell RA et al. The beneficial role of proteolysis in skeletal muscle growth and stress adaptation. Skeletal Muscle. 2016;6:16.

\footnotetext{
* Correspondence: Imegeney@ohri.ca

${ }^{1}$ Regenerative Medicine Program, Sprott Center for Stem Cell Research, Ottawa Hospital Research Institute, The Ottawa Hospital, Ottawa, ON K1H 8L6, Canada

${ }^{2}$ Department of Cellular and Molecular Medicine, University of Ottawa, Ottawa, ON, Canada

Full list of author information is available at the end of the article
}

\footnotetext{
Submit your next manuscript to BioMed Central and we will help you at every step:

- We accept pre-submission inquiries

- Our selector tool helps you to find the most relevant journal

- We provide round the clock customer support

- Convenient online submission

- Thorough peer review

- Inclusion in PubMed and all major indexing services

- Maximum visibility for your research

Submit your manuscript at www.biomedcentral.com/submit
} 